\title{
Hygienization performances of innovative sludge treatment solutions to assure safe land spreading
}

\author{
C. Levantesi • C. Beimfohr • A. R. Blanch • A. Carducci • \\ A. Gianico • F. Lucena • M. C. Tomei • G. Mininni
}

Received: 6 May 2014 / Accepted: 8 September 2014

(C) Springer-Verlag Berlin Heidelberg 2014

\begin{abstract}
The present research aims at the evaluation of the hygienization performances of innovative sludge treatment processes applied for the separated treatment of secondary sludge. Namely, two digestion pretreatments (sonication and thermal hydrolysis) and two sequential biological processes (mesophilic/thermophilic and anaerobic/aerobic digestion) were compared to the mesophilic (MAD) and thermophilic anaerobic digestion (TAD). Microbial indicators (Escherichia coli, somatic coliphages and Clostridium perfringens spores) and pathogens (Salmonella and enteroviruses), which show different resistances to treatment processes, were monitored in untreated and treated sludge. Overall, microbial load in secondary sludge was shown to be similar or lower than previously reported in literature for mixed sludge. Notably, the anaerobic/aerobic digestion process increased the removal of E. coli and somatic coliphages compared to the simple MAD and always achieved the hygienization requirement (2-logunit removal of E. coli) proposed by EU Commission in the 3rd Working Document on sludge (April 2000) for the use of treated sludges in agriculture with restriction on their application. The microbial quality limits for the unrestricted use of sludge in agriculture (no Salmonella in $50 \mathrm{~g}$ wet weight (WW) and $E$. coli $<500 \mathrm{CFU} / \mathrm{g}$ ) were always met when thermal digestion or pretreatment was applied; however, the required
\end{abstract}

Responsible editor: Gerald Thouand

C. Levantesi $(\bowtie) \cdot$ A. Carducci • A. Gianico • M. C. Tomei •

G. Mininni

CNR - Water Research Institute, Monterotondo, Rome, Italy

e-mail: levantesi@irsa.cnr.it

C. Beimfohr

vermicon AG, Munich, Germany

A. R. Blanch • F. Lucena

Department of Microbiology, University of Barcelona, Barcelona, Spain removal level (6-log-unit removal of E. coli) could not be assessed due to the low level of this microorganism in raw sludge. Observed levels of indicator removal showed a higher resistance of viral particles to thermal treatment compared with bacterial cells and confirmed the suitability of somatic coliphages as indicators in thermal treatment processes.

Keywords Sewage sludge $\cdot$ Anaerobic digestion $\cdot$ Aerobic stabilization · Pretreatments · Sludge hygienization · Somatic coliphages $\cdot$ C. perfringens $\cdot$ Salmonella $\cdot$ Enterovirus

\section{Introduction}

Large amounts of sewage sludge are produced from wastewater treatment plants worldwide and the interest in the beneficial reuse of biosolids in agriculture is growing. However, concerns about potential contamination of the food chain by pathogens in sewage sludge also rise as large numbers of human pathogens, which primarily originate from human faeces, can find their way into biosolids during wastewater treatment (Sahlström 2003; Sidhu and Toze 2009; Viau and Peccia 2009; Wong et al. 2010).

Analyzing and monitoring all pathogens potentially present in the sludge are not feasible due to their great variety, and the lack of simple and rapid specific identification techniques for their detection. It is a consolidate approach, for assessment of treatment hygienization performances and microbiological quality of products, to monitor the fate of faecal indicator microorganisms. In general, microbial indicators are non-pathogenic microorganisms, easy to determine by traditional cultivation techniques and always present in faeces in higher numbers than pathogens (WHO 2003, 2008). Bacterial, viral and parasitic pathogens have different survival capacities in the environment and different resistances to treatment 
processes; therefore, no single indicator microorganism can predict the presence of all pathogens (Harwood et al. 2005; Tandoi et al. 2012). Somatic coliphages (SOMCPH) were suggested as good microbial indicators of viruses' fate in sludge treatment processes, in particular when thermal treatment is applied (Mocé-llvina et al. 2003; Mandilara et al. 2006; Guzmán et al. 2007b; Astals et al. 2012). Sulphide-reducing clostridial spores (SRCSS) and Clostridium perfringens spores have been also proposed as possible indicators for the reduction of highly resistant pathogens, such as Cryptosporidium oocysts and helminth ova, in sludge treatment systems (Carrington et al. 1991; Guzmán et al. 2007b).

At present, specific limits for microbiological sludge quality or disinfection treatment requirements are not indicated in the 1986 European Directive on the use of sewage sludge in agriculture (European Commission: Council Directive 86/278/EEC 1986) that is still operative. However, two EU working documents on sludge have been produced since then that considered the sludge hygienization issue: the EU Working Document on sludge (2000) and the EU Working document on sludge and biowaste (2010). The EU Working Document on sludge (2000) indicates that in order to be used without restrictions, sludge should undergo an hygienization process by an "advanced treatment", which should achieve at least a 6-log-unit reduction of Escherichia coli and produce sludge complying with the following limits: no Salmonella in $50 \mathrm{~g}$ (wet weight, WW) and E. coli $<500$ colony-forming unit $(\mathrm{CFU}) / \mathrm{g}$. It is also proposed that sludge produced by "conventional treatments" should show a 2-log-unit reduction of E. coli, and its use is allowed with restrictions on its application time, site and modality. Mesophilic anaerobic digestions (MAD) at a temperature of $35{ }^{\circ} \mathrm{C}$ with a mean retention time of 15 days and thermophilic anaerobic digestions (TAD) at a temperature of at least $53{ }^{\circ} \mathrm{C}$ for $20 \mathrm{~h}$ as a batch, without admixture or withdrawal during the treatment, are indicated, among others, as conventional and advanced treatment processes, respectively. The more recent EU document only suggests the limit absence of Salmonella in 25$50 \mathrm{~g}$ and E. coli $<5 \times 10^{5} / \mathrm{g} \mathrm{WW}$ as possible criteria for the use of sludge in agriculture.

MAD is the most commonly used sludge stabilization process in large municipalities. However, the hygienization performance of this treatment is known to be very low, achieving the removal of approximately $1-2 \log$ units of common bacterial indicators (Carrington et al. 1991; Gantzer et al. 2001; Moce'-Llivina et al. 2003; Sahlström et al. 2004; Mandilara et al. 2006; Guzmán et al. 2007a, b; Pepper et al. 2010; Astals et al. 2012). Increased hygienization performance is obtained in TAD at $50-55^{\circ} \mathrm{C}$ that efficiently reduces bacterial indicators by $>3 \log$ units (Sahlström et al. 2004;
Astals et al. 2012). In respect to MAD, TAD increases methane production and reduces the retention time needed for sludge treatment. However, some drawbacks such as the poorer sludge dewaterability, lower stability and higher odour potential have limited its industrial implementation (Duran and Speece 1997). Alternatively, different combinations of sludge digestion treatments are being developed, evaluated and applied in order to achieve an appropriate quality for safe application of sludge on agricultural land (Lv et al. 2010; Astals et al. 2012; Gianico et al. 2013). These treatments can be complemented with other pretreatments (i.e. sonication and thermal or chemical hydrolysis) to improve further digestion stages (Carballa et al. 2009; Braguglia et al. 2012).

In the European project ROUTES, a separated treatment of the secondary sludge (waste-activated sludge, WAS), segregated from the more polluted primary sludge, was proposed as an alternative route for the implementation of safe land application of treated sludge (Mininni et al. 2004). With this in mind, new sludge treatment solutions were evaluated to maximize secondary sludge flock disintegration and to consistently improve organic matter reductions, methane and biogas production and sludge dewaterability. The investigated treatment solutions and their stabilization performances are described elsewhere in this issue (Gianico et al. 2014; Braguglia et al. 2014; Tomei and Carozza 2014).

The objective of this study was the evaluation of hygienization efficiency of treatment systems investigated in the ROUTES project for the production of safe sludge for land application from WAS. The hygienization performances of two sludge pretreatments (thermal hydrolysis and sonication) and two innovative combinations of biological treatments, namely the sequential mesophilic anaerobic/aerobic digestion (AA) (Novak et al. 2003) and the double mesophilic and thermophilic digestion of untreated (UMT-untreated) or sonicated sludge (UMT-sonic) (Gianico et al. 2014), were investigated in comparison to the MAD and TAD, as example for "conventional" and "advanced" sludge treatment processes (Environment DG 2000). Three microbial indicators, E. coli, somatic coliphages (SOMCPH) and C. perfringens spores, as well as two pathogens, Salmonella and enteroviruses, with different resistances to treatment processes, were monitored in untreated and treated sludge. The level of microbial contamination of WAS was also evaluated in comparison to literature data on mixed sludge quality. Additionally, compliance of treatment performances and final sludge quality levels were determined attending to the present EUproposed criteria for the reuse of sludge in agriculture (Environment DG 2000), and finally, the value of the proposed limits and microbial indicators for the assessment of sludge hygienization performances were discussed. 


\section{Materials and methods}

Sludge treatment systems

Two pretreatments (thermal hydrolysis, TH, and sonication, SON) and five biological treatments systems (MAD, TAD, AA, UMT-untreated, UMT-sonic) were investigated.

Pretreatments Thermal pretreatment was performed at $135^{\circ} \mathrm{C}$ for $20 \mathrm{~min}$ as described in Gianico et al. (2013). The disintegration by sonication was performed with an ultrasonic processor UP400S (Dr. Hielscher, Germany) operating at $300 \mathrm{~W}$ and $24 \mathrm{kHz}$. The sonotrode had a diameter of $22 \mathrm{~mm}$ making the device suitable for sample volumes of $500 \mathrm{~mL}$. Sonication energy input was set at $0.4-0.5 \mathrm{kWh} / \mathrm{kg}$ dry solid on $500 \mathrm{~mL}$ of waste-activated sludge (3.2-4.7\% $\%$ TS) placed in a $1-\mathrm{L}$ beaker with the probe allocated at $3 \mathrm{~cm}$ above the beaker bottom.

Biological treatment processes For the biological processes, laboratory-scale anaerobic glass digesters were operated in semicontinuous mode and fed with the untreated or pretreated WAS from Roma Nord wastewater treatment plant.

For the TAD, a 7-L-jacketed glass reactor, fed with untreated WAS, was operated in a semicontinuous mode as described in Gianico et al. (2013). The digester was completely mixed and maintained at the constant temperature of $55^{\circ} \mathrm{C}$ for the complete operating period of 102 days (organic loading rate (OLR) $1.8 \mathrm{~g}$ volatiles solids (VS)/L/day; hydraulic retention time (HRT) 8 days). The loading rate applied was in the range of typical full-scale anaerobic plants and similar to other authors' studies (De la Rubia et al. 2006; Toreci et al. 2009). Working at higher loads could in fact inhibit the anaerobic process, due to a significant release of ammonia deriving from intense protein degradation typical for thermophilic digestion (Han et al. 2007).

For the UMT process, digestion of sludge was carried out using four anaerobic 7-L digesters operated in semicontinuous mode. Two reactors were used to carry out the two-stage digestion of untreated WAS (UMT); the other two reactors were selected to treat the same sludge but after sonication (UMT-sonic). The two "first stage" reactors were maintained at a constant temperature of $37^{\circ} \mathrm{C}$, while two "second stage" reactors were maintained at $55{ }^{\circ} \mathrm{C}$. The OLR to the first mesophilic reactor was fixed at $3.9 \mathrm{~kg} \mathrm{VS} / \mathrm{m}^{3} /$ day $(\mathrm{HRT}=$ 5 days) and to the successive thermophilic reactor at $1.2 \mathrm{~kg}$ $\mathrm{VS} / \mathrm{m}^{3} /$ day (HRT $=10$ days), according to other studies (Ge et al. 2010; Riau et al. 2010).

For the sequential AA digestion system, two 7.4-L cylindrical glass reactors were operated in series: the untreated secondary sludge was fed daily to the anaerobic reactor and a volume of anaerobically digested sludge from this reactor, evaluated on the basis of the sludge retention time, was fed to the following aerobic reactor. Both reactors were equipped with mechanical stirrers. During the operating period (7 months), the anaerobic reactor was maintained at $37 \pm$ $0.5{ }^{\circ} \mathrm{C}$ with a sludge retention time (SRT) of 15 days, and the aerobic reactor was operated at room temperature with a SRT of 12 days. The anaerobic SRT value was selected from the lower range of values reported in the specialized literature for mesophilic anaerobic digestion (Vesilind and Spinosa 2001). Aerobic SRT has been established in order to achieve a simultaneous nitrification and denitrification; thus, it was higher than previous values proposed for the aerobic sludge posttreatment (Kumar et al. 2006; Subramanian et al. 2007), which were mainly focused to improve the solid removal efficiency and the dewaterability of the digested sludge. The OLR values, in the range of $1.42-2.54 \mathrm{~kg} \mathrm{VS} / \mathrm{m}^{3} /$ day, were higher than the average value of $\sim 1 \mathrm{~kg} \mathrm{VS} / \mathrm{m}^{3} /$ day generally applied in anaerobic mesophilic digestion of sewage sludge (Bolzonella et al. 2005). They were selected based on preliminary tests demonstrating a better performance of the AA process for highly loaded digesters (Tomei and Carozza 2014).

As indicated for advanced treatments (Environment DG 2000), the thermophilic anaerobic digestion, single or combined, was always operated at a temperature of at least $53{ }^{\circ} \mathrm{C}$ for $20 \mathrm{~h}$ as a batch, without admixture or withdrawal during the treatment. MAD was performed with a mean retention period of 15 days as required for conventional sludge treatment (Environment DG 2000).

Digestion performances of the biological processes are described in this issue (Braguglia et al. 2014; Gianico et al. 2014; Tomei and Carozza 2014) or elsewhere (Gianico et al. 2013).

\section{Samples and sampling campaigns}

Pretreatments and biological treatment processes' hygienization performances were monitored by assessing microbial indicators and pathogen levels in untreated and treated sludges. The TH and SON were analyzed during nine (TH) and four (SON) sampling campaigns for microbial indicators and two (TH) and one (SON) sampling campaigns for pathogens. The laboratory scale reactors were monitored for microbiological parameters only during periods characterized by stable digestion performances, i.e. after reaching constant VS removal rates, for both anaerobic and aerobic phases, and only for the anaerobic digestion, after reaching constant specific biogas production. In each sampling campaign, samples of the raw sludge and the final treated sludge produced by the complete processes were collected. Only for the AA process, both the performances of the single MAD and of the complete process were determined collecting the MADand AA-treated samples at each sampling campaign. In detail, the following sampling campaigns were performed: TAD (eight for E. coli and C. perfringens spores and five for 
SOMCPH), MAD and AA (seven for E. coli and $C$. perfringens spores and six for $\mathrm{SOMCPH}$ ), and UMT and UMT-sonic (four for all indicators). Additionally, Salmonella and enterovirus levels were determined during one sampling campaign for each treatment, while Salmonella spp. presence/ absence in $50 \mathrm{~g} \mathrm{WW}$ was assessed in four (TH, SON), three (TAD, MAD, AA) and two (UMT and UMT-sonic) sampling campaigns.

\section{Microbial analysis}

E. coli and Salmonella were determined following a modified pre-normative method, developed under the CEN/TC308 and defined previously in the EU project HORYZONTAL-HYG. Shortly, for E. coli, the homogenized diluted sample was inoculated on ChromoCult agar (Merck, Germany) and incubated initially at $30 \pm 1{ }^{\circ} \mathrm{C}$ for $4 \pm 0.5 \mathrm{~h}$ and then at $44 \pm 1{ }^{\circ} \mathrm{C}$ for $16 \pm 2 \mathrm{~h}$. The presence of $E$. coli was shown by the purple reaction resulting from the hydrolysis of MUG. The E. coli detection limit ranged between $1.2 \times 10^{2}$ and $2.6 \times 10^{2} \mathrm{CFU} / \mathrm{g}$ depending on the sludge dry weight (DW) content.

Salmonella presence/absence was assessed by a five-step procedure comprising: (a) pre-enrichment of $50 \mathrm{~g} \mathrm{WW}$ of sludge in buffered peptone water $\left(24 \mathrm{~h}, 36^{\circ} \mathrm{C}\right)$, (b) enrichment in Rappaport-Vassiliadis medium $\left(42^{\circ} \mathrm{C}, 24 \mathrm{~h}\right)$, selection on two media, namely (c) SMS agar $\left(42^{\circ} \mathrm{C}, 24 \mathrm{~h}\right)$ followed by (d) Hektoen enteric agar $\left(37^{\circ} \mathrm{C}, 24 \mathrm{~h}\right)$ and, finally, (e) biochemical confirmation of the colonies grown on nutrient agar by MUCAP test (Biolife Italiana, Italy). The most probable number (MPN) quantification of Salmonella was performed using the same enrichment, selection and detection systems on a serial dilution of the homogenized sample. C. perfringens spores were analyzed according to Bufton (1959). SOMCPH were analyzed by extraction procedures described by Guzmán et al. (2007a) and their enumeration by using the standardized methods ISO10705-2. Cultivable enteroviruses were eluted from samples according to USEPA standard (Anon 2003). Briefly, liquid raw sludge was conditioned by the addition of $\mathrm{AlCl}_{3}$ to a final concentration of $0.0005 \mathrm{M}$, then thoroughly mixed by shaking and centrifugation. From this point on, the pellet of the conditioned raw sludge and the other sludges were treated in the same way to elute any viruses adsorbed to the solids. Elution was performed with $10 \%$ beef extract and viruses were concentrated by organic flocculation according to Katzenelson et al. (1976). Eluted viruses were enumerated by the double-layer plaque assay using buffalo green monkey (BGM) cell line (European Collection of Animal Cell Cultures, accession number 90092601).

Statistical analysis

Statistical analyses were conducted using SigmaStat version 3.5 to assess statistically significant differences in the level of microbial indicators between raw and treated sludges for each process, and to evaluate differences in hygienization performances (E. coli, SOMCPH and C. perfringens spores log-unit removals) obtained by the different treatment solutions. Logunit removals and $\log 10$-transformed concentration values were used for all computations and tests. The MannWhitney rank sum nonparametric statistical test was used for non-normally distributed data. For normally distributed data, the unpaired $t$ test was applied; differences were considered significant at $P<0.05$.

\section{Results}

Microbiological quality of raw secondary sludge

The microbial load of the secondary sludge fed to the investigated pretreatment and treatment processes was determined by monitoring three microbial indicators (E. coli, $C$. perfringens spores and SOMCPH) and two index pathogens (Salmonella and enteroviruses). In Table 1, the obtained results are reported in comparison with literature data related to microbiological quality of mixed sludge.

Microbial indicators were always detected and were present at high concentrations in the raw secondary sludge, ranging from an average of $3.5 \times 10^{5} \mathrm{CFU} / \mathrm{g} \mathrm{DW}$ of $C$. perfringens spores to $3.7 \times 10^{6}$ plaque-forming unit $(\mathrm{PFU}) / \mathrm{g}$ DW of SOMCPH. Lower levels of bacterial indicators, approximately $10^{3} \mathrm{CFU} / \mathrm{g} \mathrm{DW}$, were also found in raw sludge, but only in few sampling campaigns (3/18). Enteroviruses were detected only in two of the analyzed samples at very low levels: 1.8 and $2.03 \mathrm{PFU} / \mathrm{g}$ DW, while Salmonella was always detected in the raw sludge, ranging from 20 to $200 \mathrm{MPN} / \mathrm{g}$ DW. The observed Salmonella concentration was within the previously reported wide range for this bacterium in mixed sludge. With the exception of Salmonella, the level of the analyzed microbial parameters in our samples was very similar or lower than previously reported for mixed sludge (see Table 1). In particular, the secondary sludge seemed to be less contaminated with enteroviruses and $\mathrm{SOMCPH}$, which were on average 1 $\log$ unit less concentrated in comparison to data previously reported for mixed sludges.

\section{Processes' hygienization performances}

The microbial inactivation level was determined by assessing presence and abundance of microbial indicators, E. coli, C. perfringens spores and $\mathrm{SOMCPH}$, in the fed and produced sludge of the investigated treatment solutions. Pathogen levels were also determined for each treatment in one or two sampling campaigns.

The microbial log-unit removal rates achieved by the analyzed pretreatment/digestion processes, as well as the numbers 
Table 1 Microbiological quality of secondary sludge in comparison to mixed sludge literature data

\begin{tabular}{|c|c|c|}
\hline & $\begin{array}{l}\text { Secondary sludge } \\
\text { Average } \\
\text { (Range) } \\
\text { (Sample number) }\end{array}$ & Mixed sludges (literature data) \\
\hline $\begin{array}{l}\text { E. coli } \\
\text { (CFU/g DW) }\end{array}$ & $\begin{array}{l}5.7 \times 10^{5} \\
\left(3.0 \times 10^{3}-2.9 \times 10^{6}\right)(18)\end{array}$ & $\begin{array}{l}4.4 \times 10^{5}-1.1 \times 10^{6} \mathrm{MPN} / \mathrm{g} \text { DW (Pourcher et al. 2005) } \\
4.6 \times 10^{3}-1.6 \times 10^{6} \mathrm{MPN} / \mathrm{g} \text { DW (Carballa et al. 2009) } \\
6.1-6.5 \log \mathrm{CFU} / \mathrm{g} \text { DW (Astals et al. 2012) } \\
6.51-6.63 \mathrm{log} \mathrm{MPN} / \mathrm{g} \text { DW (Chen et al. 2012) }\end{array}$ \\
\hline $\begin{array}{l}\text { C. perfringens spores } \\
\text { (CFU/g DW) }\end{array}$ & $\begin{array}{l}3.6 \times 10^{5} \\
\left(9.6 \times 10^{3}-1.9 \times 10^{6}\right)(18)\end{array}$ & $\begin{array}{l}4.5 \times 10^{6}-1.9 \times 10^{7} \mathrm{MPN} / \mathrm{g} \text { DW (Pourcher et al. 2005) } \\
8.4 \times 10^{4}-8.1 \times 10^{6} \mathrm{CFU} / \mathrm{g} \text { DW (Carballa et al. 2009) }\end{array}$ \\
\hline $\begin{array}{l}\text { Somatic coliphages } \\
\text { (PFU/g DW) }\end{array}$ & $\begin{array}{l}3.7 \times 10^{6} \\
\left(7.110^{5}-9.710^{6}\right)(14)\end{array}$ & $\begin{array}{l}\text { 2.8-3.9 } \times 10^{8} \mathrm{PFU} / 10 \mathrm{~g} \text { DW (Guzmán et al. 2007a, b) } \\
6.5-8.4 \log \text { PFU/g DW (Astals et al. 2012) }\end{array}$ \\
\hline $\begin{array}{l}\text { Salmonella } \\
\text { (MPN/g DW) }\end{array}$ & $\begin{array}{l}1.2 \times 10^{2} \\
\left(2 \times 10-2 \times 10^{2}\right)(4)\end{array}$ & $\begin{array}{l}\text { 1.2-3.2 MPN/g DW (Pourcher et al. 2005) } \\
6.3 \times 10^{2} \mathrm{MPN} / \mathrm{g} \text { DW (Dahab and Surampalli 2002) } \\
\text { 23.7 MPN/4 g DW (Forster-Carneiro et al. 2010) } \\
\text { 1884 } \pm 3286 \mathrm{MPN} / 4 \text { g DW (Pepper et al. 2010) } \\
5.58-6.55 \mathrm{log} \text { MPN/g DW (Chen et al. 2012) }\end{array}$ \\
\hline $\begin{array}{l}\text { Enteroviruses } \\
\text { (PFU/g DW) }\end{array}$ & $<0.1-2.03$ & $\begin{array}{l}\text { 15-18/g DW (Pourcher et al. 2005) } \\
\left.4.8 \times 10^{2}-2 \times 10^{3} / 10 \text { g DW (Guzmán et al. } 2007 \mathrm{a}, \mathrm{b}\right) \\
19.02 \pm 31.6 / 4 \text { g DW (Pepper et al. } 2010)\end{array}$ \\
\hline
\end{tabular}

${ }^{\mathrm{a}}$ Primary sludge

of treated sludge samples positive for Salmonella and other microbial indicators examined in this study, are reported in Table 2.

C. perfringens spores showed to be the most resistant indicator; they were reduced only at very high temperatures in TH $(P<0.001$ Mann-Whitney rank sum test), while no statistically significant differences in the level of this parameter was observed between raw and treated sludge $(P$ ranging from 0.1 to $0.6 t$ test) for the rest of monitored sludge treatment processes. E. coli and SOMCPH levels decreased in all the treatment processes except sonication, where no removal was observed for all the analyzed microbial parameters. Salmonella was removed to below detection limit in all treated samples but sonicated sludge.

As expected, the $\mathrm{TH}$ at $130{ }^{\circ} \mathrm{C}$ provided the highest removal of microbial parameters reducing their concentration to non-detectable levels in almost all analyzed samples.

In respect to the biological processes, only limited hygienization efficiency was obtained by MAD, no removal of $C$. perfringens spores and approximately 1-log-unit removal of E. coli, SOMCPH and Salmonella was observed.

As shown in Table 2, the aerobic stabilization phase in the $\mathrm{AA}$, in respect to the MAD, increased removal of both $E$. coli $(P<0.001 t$ test $)$ and SOMCPH $(P=0.001$ Mann-Whitney rank sum test), respectively, from 1.2 to $2.4 \log \mathrm{CFU} / \mathrm{g} \mathrm{DW}$ and from 0.9 to $2.0 \mathrm{log}$ PFU/g DW. Notably, the removal of $E$. coli in the AA system was always $\geq 2 \log$ units.

A statistically significant increase of $E$. coli $(P<0.001 t$ test) and SOMCPH ( $P=0.004$ Mann-Whitney rank sum test) removal was also obtained in TAD in respect to MAD. TAD greatly enhanced the removal of the most heat-sensitive indicator, E. coli, that was reduced to non-detectable levels in most of the treated samples, with final log-unit removal rates of $\geq 3 \log$ units on average. SOMCPH removal also increased by $1-1.5 \log$ units from 37 to $55^{\circ} \mathrm{C}$ digestion, with a final removal level of 2-2.5 log units; however, SOMCPH could still be detected in $93 \%$ of TAD-treated samples. The difference between viral and bacterial removal in sequential UMT treatment samples and TAD samples was not statistically significant $(P=0.19$, Mann-Whitney rank sum test, and $P=$ $0.099, t$ test, respectively), indicating that the thermal digestion stage was mainly responsible for disinfection in this combined process. The values of bacterial and viral removal rates in thermophilic digestion, comprising the simple (TAD) and sequential processes (UMT, UMT-sonic), confirmed the higher resistance of viral particles to thermal treatments. In thermally digested samples, as well as in TH, E. coli was always reduced to below detection limit and no differences in log-unit removal of this bacterium could be observed between the more (TH) and less intense (TAD and UMT) thermal treatments $(P=0.59$ and 0.16 , respectively; $t$ test). SOMCPH were reduced to non-detectable levels only by $\mathrm{TH}$ and in one TAD-treated sample. Consequently, their concentration in treated sludges (ranging from 3.8 to $6.3 \mathrm{log} \mathrm{PFU} / \mathrm{g}$ DW) allowed to evaluate SOMCPH reduction by all the other treatments.

Enteroviruses in the raw sludge, when detected, were at a very low concentration (Table 1) and were detected only in 
Table 2 Reduction of microbial indicators by sludge pretreatments and digestion processes

\begin{tabular}{|c|c|c|c|c|c|c|c|c|}
\hline & & $\mathrm{TH}$ & SON & TAD & MAD & $\mathrm{AA}$ & UMT & UMT-sonic \\
\hline \multirow[t]{3}{*}{ E. coli } & Log removal & $>3.2 \pm 0.7^{\mathrm{a}}$ & \multirow[t]{2}{*}{$\mathrm{NR}^{\mathrm{c}}$} & $>2.9 \pm 0.5^{\mathrm{a}}$ & \multirow[t]{2}{*}{$1.2 \pm 0.4$} & \multirow[t]{2}{*}{$2.4 \pm 0.3$} & $>3.5 \pm 0.4^{\mathrm{a}}$ & $>3.5 \pm 0.4^{\mathrm{a}}$ \\
\hline & Average \pm dev.st & $<5.3 \pm 0.9^{\mathrm{b}}$ & & $<5.3 \pm 0.4^{\mathrm{b}}$ & & & $<5.3 \pm 0.6^{\mathrm{b}}$ & $<5.3 \pm 0.6^{\mathrm{b}}$ \\
\hline & $\begin{array}{l}\text { (Positive-treated samples/ } \\
\text { total samples) }\end{array}$ & $(1 / 9)$ & $(4 / 4)$ & $(0 / 8)$ & $(7 / 7)$ & $(4 / 7)$ & $(0 / 4)$ & $(0 / 4)$ \\
\hline \multirow[t]{3}{*}{ SOMCPH } & Log removal & $>3.9 \pm 0.5^{\mathrm{a}}$ & \multirow[t]{2}{*}{$\mathrm{NR}^{\mathrm{c}}$} & \multirow[t]{2}{*}{$2.2 \pm 0.7$} & \multirow[t]{2}{*}{$0.9 \pm 0.4$} & \multirow[t]{2}{*}{$2.0 \pm 0.6$} & \multirow[t]{2}{*}{$2.3 \pm 0.4$} & \multirow[t]{2}{*}{$2.4 \pm 0.4$} \\
\hline & Average \pm dev.st & $<5.2 \pm 1.0^{\mathrm{b}}$ & & & & & & \\
\hline & $\begin{array}{l}\text { (Positive-treated samples/ } \\
\text { total samples) }\end{array}$ & $(2 / 9)$ & $(4 / 4)$ & $(4 / 5)$ & $(6 / 6)$ & $(6 / 6)$ & $(4 / 4)$ & $(4 / 4)$ \\
\hline \multirow[t]{3}{*}{ Spores } & Log removal & $>2.5 \pm 0.7^{\mathrm{a}}$ & \multirow[t]{2}{*}{$\mathrm{NR}^{\mathrm{c}}$} & \multirow[t]{2}{*}{$\mathrm{NR}^{\mathrm{c}}$} & \multirow[t]{2}{*}{$\mathrm{NR}^{\mathrm{c}}$} & \multirow[t]{2}{*}{$\mathrm{NR}^{\mathrm{c}}$} & \multirow[t]{2}{*}{$\mathrm{NR}^{\mathrm{c}}$} & \multirow[t]{2}{*}{$\mathrm{NR}^{\mathrm{c}}$} \\
\hline & Average \pm dev.st & $<5.1 \pm 0.8^{\mathrm{b}}$ & & & & & & \\
\hline & $\begin{array}{l}\text { (Positive-treated samples/ } \\
\text { total samples) }\end{array}$ & $(0 / 9)$ & $(4 / 4)$ & $(8 / 8)$ & $(7 / 7)$ & $(7 / 7)$ & $(4 / 4)$ & $(4 / 4)$ \\
\hline \multirow[t]{3}{*}{ Salmonella } & Log removal & $>0.9$ & \multirow[t]{2}{*}{ NR } & $>0.9$ & $>0.9$ & $>0.9$ & $>0.8$ & $>0.8$ \\
\hline & & $<2.3$ & & $<1.3$ & $<2.0$ & $<2.1$ & $<2.1$ & $<2.1$ \\
\hline & $\begin{array}{l}\text { (Positive-treated samples/ } \\
\text { total samples) }\end{array}$ & $(0 / 2)$ & $(1 / 1)$ & $(0 / 1)$ & $(0 / 1)$ & $(0 / 1)$ & $(0 / 1)$ & $(0 / 1)$ \\
\hline
\end{tabular}

$N R$ no reduction

${ }^{a}$ Minimum average log removal estimated by using detection limit as microbial parameter concentration in the treated sludge

${ }^{\mathrm{b}}$ Maximum average log removal estimated considering 0 as microbial parameter concentration in the treated sludge

${ }^{\mathrm{c}}$ No reduction; not statistically significantly different concentrations in raw and treated sludge (ANOVA one way and $t$ test)

one treated sludge sample. Consequently, the specific removal of these microorganisms by different treatment processes could not be evaluated. Although the detection limit for the applied enterovirus enumeration method was $<0.01 \mathrm{PFU} / \mathrm{g}$ $\mathrm{DW}$, their estimated reduction in enterovirus-positive sampling campaigns was around $2 \log$ units. Overall, it was determined that the ratio of SOMCPH/enteroviruses was around $5 \log$ units, which suggests in agreement to previous findings (Berman et al. 1981; Lewis et al. 1983; Monpoeho et al. 2000, 2004), that enteroviruses are not present or are present at very low concentrations (lower than detection limits, $<0.01 \mathrm{PFU} / \mathrm{g}$ DW) when somatic coliphages are lower than $10^{4} \mathrm{PFU} / \mathrm{g}$ DW.

Microbiological quality of treated sludge with compliance to proposed limits

The quality of the final sludge produced by the investigated processes in terms of compliance to the proposed microbial indicators limits and removal requirements (Environment DG 2000) was determined and compared to the hygienization level obtained by the conventional treatment, MAD, and the advanced treatment, TAD. Additionally, the achievement of a tentatively indicated limit of SOMCPH $<10^{4} \mathrm{PFU} / \mathrm{g}$ DW was assessed.

However, as shown in Fig. 1, the 6-log-unit E. coli removal proposed for the evaluation of advanced treatment performances could not be determined due to the low level of this bacterium in the raw WAS.
E. coli concentration above $6 \log \mathrm{CFU} / \mathrm{g}$ DW was in fact observed only in $22 \%$ of the analyzed WAS, and it was below $5 \log \mathrm{CFU} / \mathrm{g}$ DW in $45 \%$ of the analyzed samples. Consequently, a more complex and extensive analysis of a larger sludge quantity (10-100 g DW) might be necessary for the assessment of the required E. coli removal.

In Table 3, the percentages and numbers of treated samples that reached the 2-log-unit removal of $E$. coli required for conventional treatments and the proposed microbial quality limits (E. coli $<500 \mathrm{CFU} / \mathrm{g}$; no Salmonella in $50 \mathrm{~g} \mathrm{WW}$ ) for sludge treated by advanced treatments as well as the tentatively indicated limits of SOMCPH $<10^{4} \mathrm{PFU} / \mathrm{g}$ DW are reported for each sludge treatment.

Differently from what was expected for conventional treatments (Environment DG 2000), in our study, MAD did not achieve a 2-log-unit removal of $E$. coli. With the exception of sonication pretreatments, all the other analyzed treatment processes were however able to remove $2 \log$ units of E. coli, always producing sludge suitable for agricultural use with restrictions on their application.

According to what was required for advanced treatments TAD, single and combined, as well as the TH, produced sludge complying with both sludge quality limits for $E$. coli $(<500 \mathrm{CFU} / \mathrm{g})$ and Salmonella (absence in $50 \mathrm{~g} \mathrm{WW}$ ) in all or all but one samples, respectively. Surprisingly, the same limit of Salmonella required for sludge treated with advanced treatments was achieved in all digested samples including the MAD- and the AA-treated samples.

Compliance with the tentative limit of SOMCPH was achieved in $100 \%$ of the TH-treated samples but was only 


\section{E. coli}

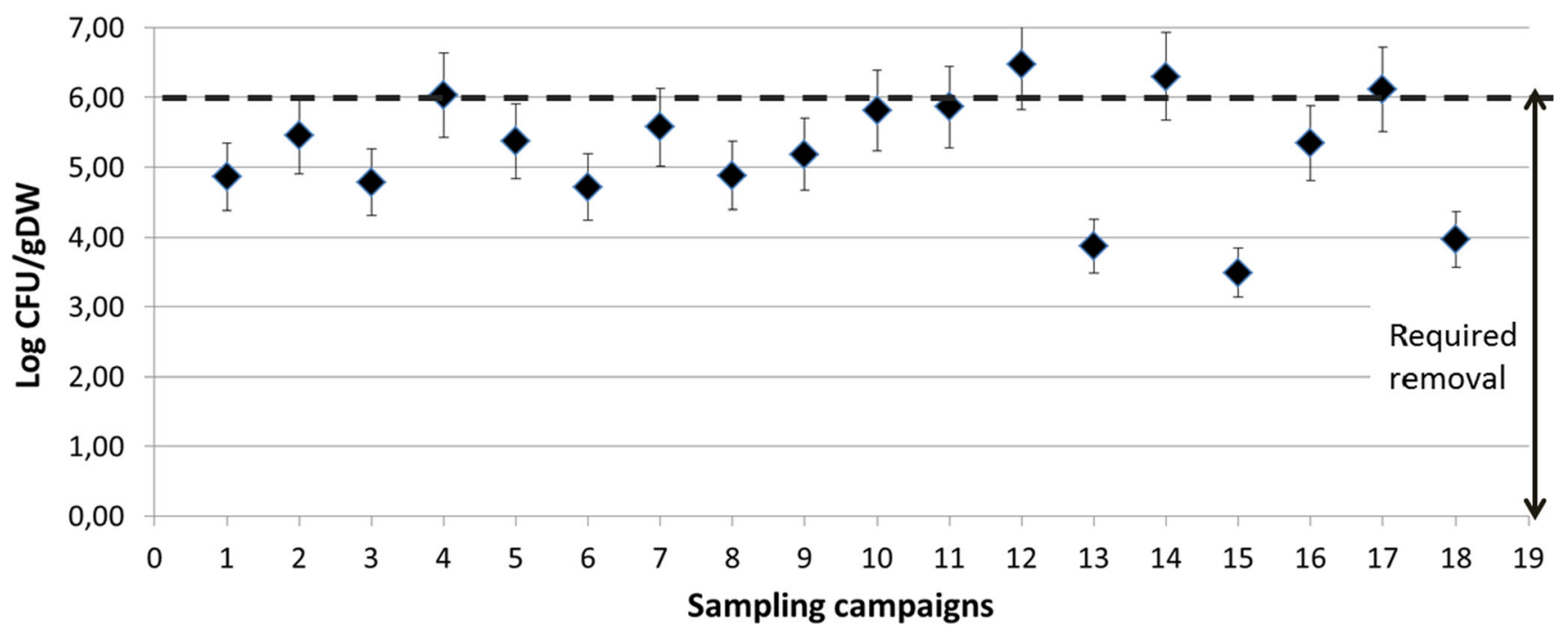

Fig. 1 E. coli concentration in WAS and proposed removal requirement for advanced treatment processes

rarely attained by TAD and UMT, in 20 and $25 \%$ of samples, respectively. This suggests that this thermal treatment might not be adequate for an efficient virus removal.

\section{Discussion}

In the ROUTES project, the segregation of the less-polluted WAS from primary sludge and its separated treatment was proposed and investigated for high potentiality $(>100,000 \mathrm{PE})$ wastewater treatment plants with the objective of reducing the risk of contamination by agricultural reuse of sludge. In particular, this study was focused on the assessment of WAS microbial contamination levels as well as the microbial inactivation performances of different sludge treatment solutions.

The obtained results partially confirmed the expected lower microbial contamination of secondary WAS in comparison to mixed and primary sludge. All the analyzed parameters, except for Salmonella, were in fact either less concentrated or in the same range of what was previously reported for mixed sludges. Notably, a lower level of enteroviruses and SOMCPH, approximately $1 \log$ unit lower on average, was observed in our secondary sludge in respect to mixed sludge literature data (Pourcher et al. 2005; Guzmán et al. 2007b; Pepper et al. 2010; Astals et al. 2012). Viruses can adsorb to various organic and inorganic solids and, according to Berg (1973), primary clarification can greatly remove viruses that are largely associated with solids in sewage. Consistently, Hejkal et al. (1981) showed that solid-associated enteroviruses account for $20-47 \%$ of the total enteroviruses in untreated wastewaters and, in agreement with other authors (Moore et al. 1974; Wellings et al. 1976), suggested that clarification contributes largely to virus removal in wastewater treatment plants. However, the observed lower virus contamination in WAS should be confirmed with larger sets of data by direct comparisons of primary and secondary sludge.

Salmonella concentrations in WAS similar or lower than those observed in our study were instead previously reported in literature for mixed sludges (Dahab and Surampalli 2002; Pourcher et al. 2005; Forster-Carneiro et al. 2010).
Table 3 Compliance to the proposed microbial indicators limits and removal requirements

${ }^{a}$ Percentage of samples (total samples)

${ }^{\mathrm{b}}$ UMT and UMT-sonic are reported together

\begin{tabular}{lllll}
\hline & $\begin{array}{l}\text { E. coli } \\
\text { 2-log-unit } \\
\text { removal }^{\mathrm{a}}\end{array}$ & $\begin{array}{l}\text { E. coli } \\
<500 \mathrm{CFU} / \mathrm{g} \mathrm{DW}^{\mathrm{a}}\end{array}$ & $\begin{array}{l}\text { Salmonella } \\
<1 / 50 \mathrm{~g} \mathrm{WW}^{\mathrm{a}}\end{array}$ & $\begin{array}{l}\text { SOMCPH } \\
<10^{4}{\mathrm{PFU} / \mathrm{g} \mathrm{DW}^{\mathrm{a}}}\end{array}$ \\
\hline $\mathrm{TH}$ & $100(9)$ & $89(9)$ & $100(4)$ & $100(9)$ \\
$\mathrm{SON}$ & $0(4)$ & $0(4)$ & $0(4)$ & $0(4)$ \\
MAD & $0(7)$ & $0(7)$ & $100(3)$ & $0(9)$ \\
$\mathrm{AA}$ & $100(7)$ & $43(7)$ & $100(3)$ & $33(6)$ \\
TAD & $100(8)$ & $100(8)$ & $100(3)$ & $20(5)$ \\
$\mathrm{UMT}^{\mathrm{b}}$ & $100(8)$ & $100(8)$ & $100(2)$ & $25(8)$ \\
\hline
\end{tabular}


Accordingly, Dahab and Surampalli (2002) observed no differences in Salmonella concentration between primary and secondary sludge.

Independently of the use of secondary sludge as feed, our data on hygienization performances of MAD and TAD confirmed recent literature for these treatments. A very limited disinfection capacity of MAD was observed and removal levels were very similar to those reported in literature: approximately 1-log-unit removal of SOMCPH (Mandilara et al. 2006; Guzmán et al. 2007a, b; Astals et al. 2012), 1- to 2log-unit removal of E. coli and Salmonella (Gantzer et al. 2001; Horan et al. 2004; Astals et al. 2012) and no removal of spores (Sahlström et al. 2004; Guzmán et al. 2007b; Carballa et al. 2009) were measured. Improved hygienization was obtained by TAD with removal performances, for $E$. coli ( $\geq 3 \log$ units), SOMCPH (2-2.5 log units) and C. perfringens spores (no removal), comparable to previously reported data (Carrington et al. 1991; Sahlström et al. 2004; Aitken et al. 2005; Astals et al. 2012). No reduction of microbial parameters was measured after sonication, and consistently, the sequential UMT process, with or without sonication pretreatment, showed hygienization performances comparable to $\mathrm{TAD}$, indicating that thermal treatment was the main driver for microbial inactivation in the UMT systems.

As expected, thermal pretreatment was very efficient in the inactivation of the analyzed microbial parameters including the very resistant $C$. perfringens spores. All the microbial indicators were reduced to non-detectable levels with an estimated logarithmic removal of $>3.9 \pm 0.5,>2.5 \pm 0.7$ and $>3.2 \pm$ 0.7 , respectively, for $\mathrm{SOMCPH}, C$. perfringens spores and E. coli. Consistently, previous studies on thermal treatment processes reported a similar C. perfringens spore removal rate at $130{ }^{\circ} \mathrm{C}$ (Carballa et al. 2009), while little or no removal (0.3-log-unit reduction) of this indicator was observed at $80{ }^{\circ} \mathrm{C}$ for 90 min (Mocé-Llvina et al. 2003). Besides being utilized as microbial indicators, some Clostridium species are known pathogenic microorganisms and other species were reported as causes of big economic losses in dairy industries when cows are fed with silage fertilized by digested residue (Sahlström 2003). However, most endospore-forming bacteria are already present in the soil and whether their potential increase by added treated sludge might increase the risk of the reuse of biosolid in agriculture would require further investigation. SOMCPH inactivation levels similar or higher than those observed by $\mathrm{TH}$ in our study were previously reported by less intense thermal treatments $\left(80^{\circ} \mathrm{C}\right.$ for $10 \mathrm{~min}$ ) (Astals et al. 2012) suggesting that, differently from what was observed for $C$. perfringens spores, high temperature applied in TH might not be necessary for an efficient virus inactivation.

The hygienization performance of the sequential AA process was evaluated for the first time, showing an increased removal of SOMCPH and E. coli in respect to the simple
MAD. In particular, inactivation levels in between those reported for MAD and TAD were obtained for E. coli (2.4-logunit reduction on average) and a removal performance (2-logunit removal) comparable to that obtained by TAD was achieved for the viral indicators. Notably, the AA process always achieved the E. coli 2-log-unit removal requirement for the production of sludge suitable for agricultural reuse.

Although operated as described for conventional treatment, namely "mesophilic anaerobic digestion" at a temperature of $35^{\circ} \mathrm{C}$ with a mean retention period of 15 days (Environment DG 2000), in this study, MAD never reached the expected E. coli 2-log-unit removal of conventional treatment. Similar MAD E. coli removal performances were reported by Gantzer et al. (2001) and Horan et al. (2004), suggesting that a hygienization performance lower than expected by Environment DG (2000) might be obtained by the described process. On the contrary, in agreement with what was expected by "advanced treatment processes", the thermophilic digestion, either single (TAD) or combined (UMT), as well as the $\mathrm{TH}$, always produced sludge conforming to the microbial quality limits for the unrestricted use of sludge in agriculture (no Salmonella in $50 \mathrm{~g} \mathrm{WW}$ and E. coli $<500 \mathrm{CFU} / \mathrm{g} \mathrm{DW}$ ). However, the 6-log-unit E. coli removal performance could not be assessed due to the low level of $E$. coli in the examined WAS, ranging from $3.0 \times 10^{3}$ to $2.9 \times 10^{6} \mathrm{CFU} / \mathrm{g}$ DW. Similar E. coli values are reported in literature for raw mixed sludge (Pourcher et al. 2005; Carballa et al. 2009; Astals et al. 2012; Chen et al. 2012), indicating that the criteria of 6-log-unit E. coli removal proposed for advanced processes evaluation might not be easily applicable in sewage sludge treatments, as raw sludge might not possess a sufficient initial E. coli concentration.

In our study, the Salmonella limit for sludge treated by advanced treatment (absence in $50 \mathrm{~g} \mathrm{WW}$ ) was always achieved by MAD. Other authors (Gantzer et al. 2001; Sahlström et al. 2004; Guzmán et al. 2007b) instead frequently detected this bacterium in $50 \mathrm{~g} \mathrm{WW}$ in MAD-treated sludge in spite of their reported bacterial removal performance being very similar to that obtained in our study. In general, a wide range of concentrations from 1.2 to 3.2 MPN/g DW (Pourcher et al. 2005) to 5.58-6.55 log MPN/g DW (Chen et al. 2012) is reported for this bacterium in raw sludges. Consequently, also the achievement of the proposed Salmonella limit by digestion treatment can be highly dependent on the initial concentration of this bacterium and might vary in different studies.

Enteroviruses were scarcely detected in the treated sludge; however, they were either rarely detected or present in low numbers in the analyzed raw sludge fed to the treatment systems, confirming their reported poor value as an indicator of sludge treatment performance (Viau and Peccia 2009; Pepper et al. 2010).

Previous research indicated SOMCPH as a valuable alternative indicator of virus removal in thermal treatments 
(Moce'-Llivina et al. 2003; Guzmán et al. 2007b; Astals et al. 2012). In our study, the observed lower SOMCPH inactivation in TAD in comparison to E. coli corroborates previous findings (Moce'-Llivina et al. 2003; Mandilara et al. 2006; Guzmán et al. 2007b; Astals et al. 2012) showing the higher resistance of viral particles to thermal treatments and suggesting a low reliability of bacteria as an indicator of viruses' fate at temperatures $>55{ }^{\circ} \mathrm{C}$. SOMCPH were always present and could be easily quantified in raw-treated sludge samples with the exception of TH effluent, and diverse removal levels could be estimated in treatments with different disinfection power. Consequently, SOMCPH are showing to be an appropriate viral indicator for measuring the efficacy of microbial reduction by new hygienization processes. The proportion between SOMCPH and enteroviruses was around 4-5 log units in agreement with previous studies (Berman et al. 1981; Lewis et al. 1983; Monpoeho et al. 2000, 2004), suggesting that enteroviruses are not present or at very low concentration (lower than detection limits, $<0.01 \mathrm{PFU} / \mathrm{g} \mathrm{DW}$ ) when somatic coliphages are lower than $10^{4} \mathrm{PFU} / \mathrm{g}$ DW. In our study, this SOMCPH level was tentatively applied to estimate removal performances of different processes and it allowed, in contrast to limits based on bacterial indicators, to differentiate more and less intense thermal treatments. It was also clearly shown that intense thermal treatments such as TH are required for the achievement of this limit while TAD, when operated as proposed for advanced treatment, only rarely reduced the SOMCPH concentration below $10^{4} \mathrm{PFU} / \mathrm{g}$ DW and consequently might not be efficient in the reduction of pathogenic viruses. However, the reliability of somatic coliphages and of the proposed limit as an indicator of the presence and removal of human pathogenic enteroviruses in sludge treatment will be considered and confirmed on a larger set of data in further studies.

\section{Conclusions}

As described above, hygienization performances of innovative treatment processes, applied for the stabilization of WAS, were investigated also considering conformity to the proposed EU quality requirements for the reuse of sludge in agriculture. Additionally, the value of microbial indicators for the assessment of sludge treatment performances was evaluated. In the following, the main conclusions drawn are reported:

- Sludge thermal treatments, as expected, produced the sludge of higher microbiological quality. Good hygienization performances were obtained by TAD that always removed bacterial indicators and pathogens, to below detectable level. Nevertheless, more intense thermal treatments, such as the TH, were shown to be necessary for the efficient reduction of viruses and of very resistant $C$. perfringens spores.

- The aerobic phase, in the sequential AA treatment, was shown to greatly contribute to the reduction of microbial load, allowing the achievement of the microbial quality levels proposed for the reuse of sludge in agriculture with restriction on their application. Only limited microbial load reduction was obtained by anaerobic digestion at lower temperature $\left(37^{\circ} \mathrm{C}\right)$ and by mild sonication pretreatment.

- Bacterial and viral pathogens were only rarely detected and were present at low levels in the analyzed untreated and treated sludge, confirming their limited values as monitoring parameters for sludge hygienization performances.

- Conventional bacterial indicators such as E. coli were shown to be very sensible to thermal treatments. In particular, the observed levels of indicator removal showed higher resistance of viral particles to thermal treatment compared to bacterial cells and confirmed the suitability of somatic coliphages as viral indicators in thermal treatment processes. Based on obtained and previously reported SOMCPH/enteroviruses ratios, the SOMCPH level of $<10^{4} \mathrm{PFU} / \mathrm{g}$ DW corresponding to no or very limited enteroviruses presence in sludge was tentatively indicated as possible sludge quality limit.

Acknowledgments This project has received funding from the European Unions Seventh Programme for research, technological development and demonstration under grant agreement 265156. The authors acknowledge Dr. Camilla Braguglia for the precious coordination of the work on the separated treatment of WAS for safe land reuse, and for the helpful suggestion for the paper.

\section{References}

Aitken MD, Sobsey MD, Shehee M, Blauth KE, Hill VR, Farrell JB, Nappier SP, Walters GW, Crunk PL, van Abel N (2005) Laboratory evaluation of thermophilic/anaerobic digestion to produce Class A biosolids. Inactivation of pathogens and indicator organisms in a continuous-flow reactor followed by batch treatment. Water Environ Res 77:3028-3036

Anon (2003) USEPA 625/R-92/013. Control of Pathogens and Vector Attraction in Sewage Sludge. Cincinnati, OH: UnitedStates Environmental Protection Agency

Astals S, Venegas C, Peces M, Jofre J, Lucena F, Mata-Alvarez J (2012) Balancing hygienization and anaerobic digestion of raw sewage sludge. Water Res 46(19):6218-27

Berg G (1973) Removal of viruses from sewage, effluents, and waters I. A review. Bull World Health Organ 49(5):451-60

Berman D, Berg G, Safferman S (1981) A method for recovering viruses from sludge. J Virol Methods 3:283-291

Bolzonella D, Pavan P, Battistoni P, Cecchi F (2005) Mesophilic anaerobic digestion of waste activated sludge: influence of the solid retention time in the wastewater treatment process. Process Biochem 40:1453-1460 
Braguglia CM, Gagliano MC, Rossetti S (2012) High frequency ultrasound pretreatment for sludge anaerobic digestion: effect on floc structure and microbial population. Bioresour Technol 110:43-49

Braguglia CM, Coors A, Gallipoli A, Gianico A, Guillon E, Kunkel U, Mascolo G, Richter E, Tomei MC, Ternes TA, Mininni G (2014) Quality assessment of digested sludge produced by advanced stabilization processes. Environ Sci Pollut Res: submitted to this special issue

Bufton AW (1959) A note on the enumeration of thermophilic sulphitereducing bacteria. J Appl Bacteriol 22:278-280

Carballa M, Omil F, Lema JM (2009) Influence of different pretreatments on anaerobically digested sludge characteristics: suitability for final disposal. Water Air Soil Pollut 199:311-321

Carrington EG, Pike EB, Auty D, Morris R (1991) Destruction of faecal bacteria, enteroviruses and ova of parasites in wastewater sludge by aerobic thermophilic and anaerobic mesophilic digestion. Water Sci Technol 24:377-380

Chen Y, Fu B, Wang Y, Jiang Q, Liu H (2012) Reactor performance and bacterial pathogen removal in response to sludge retention time in a mesophilic anaerobic digester treating sewage sludge. Bioresour Technol 106:20-26

Dahab MF, Surampalli RY (2002) Effects of aerobic and anaerobic digestion systems on pathogen and pathogen indicator reduction in municipal sludge. Water Sci Technol 46:181-187

de la Rubia MA, Perez M, Romero LI, Sales D (2006) Effect of solids retention time (SRT) on pilot scale anaerobic thermophilic sludge digestion. Process Biochem 41:79-86

Duran M, Speece RE (1997) Temperature-staged anaerobic processes. Environ Technol 18:747-753

Environment DG, EU, (2000). Working Document on Sludge 3rd Draft, Brussels, 27 April 2000, ENV.E.3/LM.http://ec.europa.eu/ environment/waste/sludge/pdf/sludge_en.pdf. Accessed 18 March 2014

European Commission: Council Directive 86/278/EEC of 12 June 1986 on the protection of the environment, and in particular of the soil, when sewage sludge is used in agriculture

Forster-Carneiro T, Riau V, Perez M (2010) Mesophilic anaerobic digestion of sewage sludge to obtain Class B biosolids: microbiological methods development. Bioresour Technol 20

Gantzer C, Gaspard P, Galvez L, Huyard A, Domouthier N, Schwartzbrod J (2001) Monitoring of bacterial and parasitological contamination during various treatment of sludge. Water Res 35(16):3763-3770

Ge H, Jensen PD, Batstone DJ (2010) Pre-treatment mechanisms during thermophilic-mesophilic temperature phased anaerobic digestion of primary sludge. Water Res 44:123-130

Gianico A, Braguglia CM, Cesarini R, Mininni G (2013) Reduced temperature hydrolysis at $134{ }^{\circ} \mathrm{C}$ before thermophilic anaerobic digestion of waste activated sludge at increasing organic load. Bioresour Technol 143:96-103

Gianico A, Braguglia CM, Gallipoli A, Mininni G (2014) Innovative twostage mesophilic/thermophilic anaerobic degradation of sonicated sludge: performances and energy balance. Environ Sci Pollut Res: submitted to this special issue

Guzmán C, Jofre J, Montemayor M, Lucena F (2007a) Occurrence and levels of indicators and selected pathogens in different sludges and biosolids. J Appl Microbiol 103(6):2420-2429

Guzmán C, Jofre J, Blanch AR, Lucena F (2007b) Development of a feasible method to extract somatic coliphages from sludge, soil and treated biowaste. J Virol Methods 144:41-48

Han Y, Li YY, Ren YX, Yan F (2007) Thermophilic anaerobic digestion of thermal pretreated WWTP sludge. Acta Sci Circum 27(7):1174-1180

Harwood VJ, Levine AD, Scott TM, Chivukula V, Lukasik J, Farrah SR, Rose JB (2005) Validity of the indicator organism paradigm for pathogen reduction in reclaimed water and public health protection. Appl Environ Microbiol 71(6):3163-3170

Hejkal TW, Wellings FM, Lewis AL, LaRock PA (1981) Distribution of viruses associated with particles in waste water. Appl Environ Microbiol 41(3):628-634

Horan NJ, Fletcher L, Betmal SM, Wilks SA, Keevil CW (2004) Die-off of enteric bacterial pathogens during mesophilic anaerobic digestion. Water Res 38(5):1113-1120

Katzenelson E, Fattal B, Hostovesky T (1976) Organic flocculation: an efficient second-step concentration method for the detection of viruses in tap water. Appl Environ Microbiol 32(4):638-639

Kumar N, Novak JT, Murthy S (2006) Effect of secondary aerobic digestion on properties of anaerobic digested biosolids. Water Environmental Federation 79th Annual Technical Exhibition and Conference, Dallas, 6806-6829

Lewis MA, Nath MW, Johnson JC (1983) A multiple extractioncentrifugation method for the recovery of viruses from wastewater treatment plant effluents and sludges. Can J Microbiol 29:16611670

Lv W, Schanbacher FL, Yu Z (2010) Putting microbes to work in sequence: recent advances in temperature-phased anaerobic digestion processes. Bioresour Technol 101(24):9409-94014

Mandilara G, Mavridou A, Lambiri M, Vatopoulos A, Rigas F (2006) The use of bacteriophages for monitoring the microbiological quality of sewage sludge. Environ Technol 27:367-370

Mininni G, Braguglia CM, Ramadori R, Tomei MC (2004) An innovative sludge management system based on separation of primary and secondary sludge treatment. Water Sci Technol 50(9):145-153

Moce'-Llivina L, Muniesa M, Pimenta-Vale H, Lucena F, Jofre J (2003) Survival of bacterial indicator species and bacteriophages after thermal treatment of sludge and sewage. Appl Environ Microbiol 69(3):1452-1456

Monpoeho S, Dehee A, Mignotte B, Schwartzbrod L, Marechal V, Nicolas JC, Billaudel S, Ferre V (2000) Quantification of enterovirus RNA in sludge samples using single tube real-time RT-PCR. Biotechniques 29:88-93

Monpoeho A, Maul C, BonninL PS, Ranarijaona S, Billaudel S, Ferré V (2004) Clearance of human-pathogenic viruses from sludge: study of four stabilization processes by real-time reverse transcription-PCR and cell culture. Appl Environ Microbiol 70(9):5434-5440

Moore BE, Funderburg SL, Sagik BP, Malina JF (1974) Application of viral concentration techniques to field sampling. In: Malina JF, Sagik BP (eds) Virus survival in water and wastewater systems. University of Texas, Austin, Center for Research in Water Resources, pp 3-15

Novak JT, Sadler MS, Murthy SN (2003) Mechanism of floc destruction during anaerobic and aerobic digestion and the effect on conditioning and dewatering of biosolids. Water Res 37:3136-3144

Pepper IL, Brooks JP, Sinclair RG, Gurian PL, Gerba CP (2010) Pathogens and indicators in United States Class B biosolids: national and historic distributions. J Environ Qual 39(6):2185-2190

Pourcher AM, Morand P, Picard-Bonnaud F, Billaudel S, Monpoeho S, Federighi M, Ferré V, Moguedet G (2005) Decrease of enteric micro-organisms from rural sewage sludge during their composting in straw mixture. Appl Microbiol 99(3):528-539

Riau V, De la Rubia MA, Pérez M (2010) Temperature-phased anaerobic digestion (TPAD) to obtain Class A biosolids: a semi-continuous study. Bioresour Technol 101:2706-2712

Sahlström L (2003) A review of survival of pathogenic bacteria in organic waste used in biogas plants. Bioresour Technol 87:161-166

Sahlström L, Aspan A, Bagge E, Danielsson-Tham ML, Albihn A (2004) Bacterial pathogen incidences in sludge from Swedish sewage treatment plants. Water Res 38(8):1989-1994

Sidhu JPS, Toze SG (2009) Human pathogens and their indicators in sludge: a literature review. Environ Int 35:187-201 
Subramanian S, Kumar N, Murthy SN, Novak JT (2007) Effect of anaerobic digestion and anaerobic/aerobic digestion processes on sludge dewatering. J Residuals Sci Technol 4:17-23

Tandoi V, Levantesi C, Toze S, Böckelmann U, Divizia M, AyusoGabella N, Salgot M, La Mantia R, Grohmann E (2012) Water quality analysis - microbiological hazards. In: Kazner C, Wintgens T, Dillon P (eds) Water reclamation technologies for safe managed aquifer recharge. IWA Publishing, London, European Commission, pp 171-196

Tomei MC, Carozza N (2014) Sequential anaerobic/anaerobic digestion for enhanced sludge stabilization: comparison of the process performance for mixed and waste sludge. Environ Sci Pollut Res: submitted to this special issue

Toreci I, Kennedy KJ, Droste RL (2009) Evaluation of continuous mesophilic anaerobic sludge digestion after high temperature microwave pretreatment. Water Res 43:1273-1284

Vesilind PA, Spinosa L (2001) Production and regulations. In: Spinosa L, Vesilind PA (eds) Sludge into biosolids - processing, disposal. Utilization. IWA Publishing, London, pp 3-18
Viau E, Peccia J (2009) Survey of wastewater indicators and human pathogen genomes in biosolids produced by Class A and Class B stabilization treatments. Appl Environ Microbiol 75(1):164-74

Wellings FM, Lewis AL, Mountain CW (1976) Demonstration of solidsassociated virus in wastewater and sludge. Appl Microbiol 31:354 358

WHO (2003) Assessing microbial safety of drinking water: improving approaches and methods. In: Dufour A, Snozzi M, Koster W, Bartram J, Ronchi E, Fewtrell L (eds) Published on behalf of the World Health Organization and the Organisation for Economic Co-operation and Development. IWA Publishing Alliance, London

WHO (2008) Guidelines for Drinking-water quality Third edition Incorporating the first and second Addenda Volume 1 Recommendations World Health Organisation, Geneva

Wong K, Onan BM, Xagoraraki I (2010) Quantification of enteric viruses, pathogen indicators, and salmonella bacteria in Class B anaerobically digested biosolids by culture and molecular methods. Appl Environ Microbiol 76(19):6441-6448 